DIE .

ENGLISCHE VERFASSUNG

BAND II 



\title{
DIE ENGLISCHE VERFASSUNG
}

\author{
VON \\ A. LAWRENCE LOWELL \\ PROFESSOR DER STAATSWISSENSCHAFT AN DER HARVARD-UNIVERSITÄT
}

\section{Autorisierte deutsche Ausgabe}

Herausgegeben und übersetzt von

Regierungsrat Dr. Herr, unter Mithilfe des

Regierungs-Assessors Freiherrn v. Richthofen

\section{BAND II}

Verlag von Veit \& Comp. / Leipzig 1913 
Alle Rechte vorbehalten.

Druck von Metzger \& Wittig in Lelpzig. 